\title{
Micro Empirical Evidence on Price Adjustment
}

\author{
Mengfei Xiao ${ }^{1, a}$, Yue-Da HSIEH ${ }^{1, b}$ and Peiyuan Xie ${ }^{1, c}$ \\ ${ }^{1}$ Department of Economics, University of Nottingham, Ningbo 315100, China \\ axiaomengfeiapp@163.com, 'by14064@nottingham.edu.cn, czy14908@nottingham.edu.cn
}

Keywords: Micro Empirical;Evidence;Price Adjustment

Abstract. This essay categorizes the empirical evidence by developed countries firstly and developing countries secondly. Within these two groups, this essay divides each group into two subgroups, by general and specific evidence. In addition, we allow the inclusion of evidence on seasonal price changes on developed countries.

\section{Introduction}

Since the development of New Keynesian Models provided theoretical foundations for price staggering behavior, it is thus a natural attempt to delve into real world price setting policy at micro-economic level (Romer, 2012). The distinct feature between time-dependent models (TDP) and state-dependent models (SDP) had been subsequently developed to model price staggering behavior and were tested by plotting in the microeconomic data (Walsh, 2010). Vast attempts have been devoted in the investigations of price setting behaviors by plotting in price data (normally as Consumer Price Index). The idiosyncratic feature of this essay is not matching the price data to the theoretical models; rather, to provide a qualitative measure on sheer price behavior across different regions worldwide.

\section{Empirical Evidence for Developed Countries}

This part will analyze the empirical evidence on individual consumer price data, focusing on developed area, especially Europe. The data are conducted on a common sample of 50 goods or services, during the January 1996 to January 2001. Moreover, the 50 products are categorized into five kinds, shown in Table 1. For data harmonizing, the product turnover is considered and there is a control for sample differences in inflation. In addition, the effect of sales is considered as well, which will be discussed further as a specific issue in the last part.

\section{Table 1}

Approximating Consumer Goods with 50 Product Categories

\begin{tabular}{|c|c|}
\hline General category & Specific category \\
\hline $\begin{array}{l}\text { Unprocessed food } \\
\text { categories }\end{array}$ & Steak, fresh fish, lettuce, banana \\
\hline $\begin{array}{l}\text { Processed food } \\
\text { categories }\end{array}$ & Milk, sugar, frozen spinach, mineral water, coffee \\
\hline Energy (oil) products & Gasoline for heating, two types of fuels \\
\hline $\begin{array}{l}\text { Non-energy industrial } \\
\text { goods }\end{array}$ & $\begin{array}{l}\text { Socks, jeans, sport shoes, shirt, acrylic paint, cement, toaster, electric bulb, } 1 \\
\text { type of furniture, towel, car tire, television set, dog food, tennis ball, Lego } \\
\text { box or equivalent, toothpaste, suitcase }\end{array}$ \\
\hline Services & $\begin{array}{l}\text { Dry cleaning; hourly rate of an electrician; hourly rate of a plumber; } \\
\text { domestic services; hourly rate in a garage; car wash; balancing of wheels; } \\
\text { taxi; movie; videotape rental; photo development; hotel room; glass of } \\
\text { beer in a bar; meal in a restaurant; hot-dog; Coca-cola or equivalent, in a } \\
\text { bar, men's haircut; ladies' hairdressing }\end{array}$ \\
\hline
\end{tabular}

Note: If one product category was not available, it was replaced by a similar product or-in a few cases-left out (for example, energy products are not covered in Spain).

(Table 1, Emmanuel, 2006) 
Based on the table 1, there are some basic facts. Generally, the mean duration of a price spell in euro is 13 months and monthly 15.1\% adjustment, which is a relatively lagged price adjustment, showing the stickiness. However, considering different dimensions, it suggests that various flexibilities result from different considerations.

Firstly, the price changes are relatively frequent for energy products and unprocessed food, but infrequent for processed food and services correspondingly, which means rigidity effects give more importance on service area. Furthermore, Emmanuel (2006) pointed that frequent price change exists more common in capital-intensive industry than labor-intensive industry. Correspondingly, the average price adjustment in energy is $78 \%$ in a given month, but that in services is only 5.6\%(Table 2). Besides, restricted regulation on price could explain the stickiness in some areas such as processed food.

Frequency of Price Changes by Product Types ${ }^{\mathrm{a}}$

\begin{tabular}{|c|c|c|c|c|c|c|c|}
\hline & $\begin{array}{l}\text { Unprocessed } \\
\text { food }\end{array}$ & $\begin{array}{l}\text { Processed } \\
\text { food }\end{array}$ & $\begin{array}{c}\text { Energy } \\
\text { (oil } \\
\text { products) }\end{array}$ & $\begin{array}{c}\text { Nonenergy } \\
\text { industrial } \\
\text { goods }\end{array}$ & Services & $\begin{array}{l}\text { Total }^{b} \\
\text { country } \\
\text { weights }\end{array}$ & $\begin{array}{c}\text { Total }^{c} \\
\text { euro area } \\
\text { weights }\end{array}$ \\
\hline Austria & 37.5 & 15.5 & 72.3 & 8.4 & 7.1 & 15.4 & 17.1 \\
\hline Belgium & 31.5 & 19.1 & 81.6 & 5.9 & 3.0 & 17.6 & 15.6 \\
\hline Germany & 25.2 & 8.9 & 91.4 & 5.4 & 4.3 & 13.5 & 15.0 \\
\hline Spain $^{\mathrm{d}}$ & 50.9 & 17.7 & n.a. & 6.1 & 4.6 & 13.3 & 11.5 \\
\hline Finland & 52.7 & 12.8 & 89.3 & 18.1 & 11.6 & 20.3 & - \\
\hline France & 24.7 & 20.3 & 76.9 & 18.0 & 7.4 & 20.9 & 20.4 \\
\hline Italy & 19.3 & 9.4 & 61.6 & 5.8 & 4.6 & 10.0 & 12.0 \\
\hline Luxembourg & 54.6 & 10.5 & 73.9 & 14.5 & 4.8 & 23.0 & 19.2 \\
\hline Netherlands & 30.8 & 17.3 & 72.6 & 14.2 & 7.9 & 16.2 & 19.0 \\
\hline Portugal & 55.3 & 24.5 & 15.9 & 14.3 & 13.6 & 21.1 & 18.7 \\
\hline Euro area & 28.3 & 13.7 & 78.0 & 9.2 & 5.6 & 15.1 & 15.8 \\
\hline United States & 47.7 & 27.1 & 74.1 & 22.4 & 15.0 & 24.8 & 27.2 \\
\hline
\end{tabular}

(Table 2, Emmanuel, 2006)

Secondly, regarding to the price change directions, Figure 1 illustrates that the price increase and reduction have different effects in magnitude and frequency. When the price rises, it seems to be high frequency with small size. On the contrary, infrequent and sizeable price adjustment happens when decreasing.

\section{Characterizing Price Increases and Price Decreases}

a. Frequency

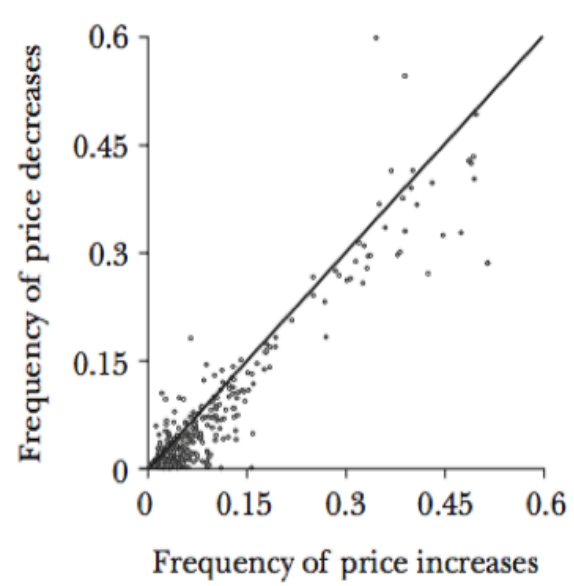

b. Average size

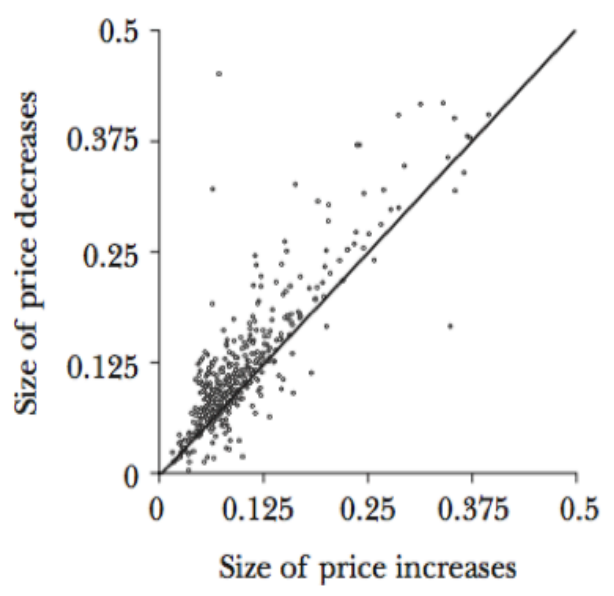

Sources: National Central Banks calculations on data from the national statistical institutes. Notes: Pooled data of 50 product categories in nine countries. (Finland is not included.)

(Figure 1, Emmanuel, 2006) 
Generally, stickiness is common, but there are various factors affecting the frequency and size in the different degrees. As well, there are also some other evidence proving the price stickiness in developed countries.

Table 3 analyzes the estimate of monthly mean frequency of CPI price changes, which clearly exhibits nominal stickiness, with a mean frequency of $19 \%$ per month. The degree of stickiness varies across countries, with prices in the Euro area changing less frequently than those in U.S. and developing countries. Next, the section will mainly focus on one typical country case, with a high-frequency data set of prices reported in Hungary.

Monthly Mean Frequency of CPI Price Changes

\begin{tabular}{|c|c|c|c|}
\hline Country & Paper & Sample Period & Frequency (in \%) \\
\hline Austria & Baumgartmer ef al. (2005) & $1996: 01-2003: 12$ & 15.1 \\
\hline Belgium & Aucremanne and Dhyne (2004) & 1989:01-2001:01 & 16.9 \\
\hline \multirow[t]{2}{*}{ Brazil } & Barros of al. (2009) & $1996: 03-2008: 12$ & 37.2 \\
\hline & Gourvea (2007) & $1996: 01-2006: 12$ & 37.0 \\
\hline Chile & Medina et al. (2007) & 1999:01-2005:07 & 46.1 \\
\hline Denmark & Hansen and Hansen (2006) & $1997: 01-2005: 12$ & 17.3 \\
\hline Euro Area & Dhyne of al. (2006) & 1996:01-2001:01 & 15.1 \\
\hline Finland & Vilmumen and Laakkonen (2005) & $1997: 01-2003: 12$ & 16.5 \\
\hline France & Baudry et al. (2007) & $1994: 07-2003: 02$ & 18.9 \\
\hline Germany & Hoffmann and Kurz-Kim (2006) & 1998:02-2004:01 & 11.3 \\
\hline Hungary & Gabriel and Reiff (2008) & $2001: 12-2007: 06$ & 15.1 \\
\hline Israel & Baharad and Eden (2004) & $1991: 01-1992: 12$ & 24.5 \\
\hline Italy & Fabiani et al. (2006) & $1996: 01-2003: 12$ & 10.0 \\
\hline Japan & Saita of al. (2006) & 1999:01-2003:12 & 23.1 \\
\hline Luxembourg & Lunnemann and Matha (2005) & $1999: 01-2004: 12$ & 17.0 \\
\hline Mexico & Gagnon (2009) & $1994: 01-2004: 12$ & 29.4 \\
\hline Netherlands & Jonker of al. (2004) & $1998: 11-2003: 04$ & 16.5 \\
\hline Norway & Wulfsberg (2009) & $1975: 01-2004: 12$ & $21.3(21.9)$ \\
\hline Portugal & Dias et al. (2004) & 1992:01-2001:01 & 22.2 \\
\hline Sierra Leone & Kovanen (2006) & $1999: 01-2003: 04$ & 51.5 \\
\hline Slovakia & Coricelli and Horvath (2006) & $1997: 01-2001: 12$ & 34.0 \\
\hline South Africa & Creamer and Rankin (2008) & $2001: 12-2006: 02$ & 16.0 \\
\hline Spain & Álvarez and Hernando (2006) & 1993:01-2001:12 & 15.0 \\
\hline United Kingdom & Bunn and Ellis (2009) & $1996: 01-2006: 01$ & $15(19)$ \\
\hline \multirow[t]{3}{*}{ United States } & Bils and Klenow (2004) & $1995: 01-1997: 12$ & 26.1 \\
\hline & Klenow and Kryvts ov (2008) & $1988: 02-2005: 01$ & $29.9(36.2)$ \\
\hline & Nakamura and Steinsson (2008a) & $1988: 01-2005: 12$ & $21.1(26.5)$ \\
\hline
\end{tabular}

Notes: Source: Álvarez (2008) with three additional studies, Barros et al. (2009), Bunn and Ellis (2009) and Wulfsberg (2009), and updated versions of Gagnon (2009), Creamer and Rankin (2008), and Klenow and Kryvtsov (2008). For studies that report frequencies of both regular (i.e., non-sale) and posted prices, the figures in parentheses correspond to posted prices. Frequencies for Nakamura and Steinsson (2008a) figures in parentheses correspond to posted prices. Frequencies for Nakamura and Steinsson (2008a)
correspond to the $1998-2005$ sample period (for contiguous observations, excluding substitutions). For Germany, frequencies refer to the sample considering item replacements and non-quality adjusted data. The Spanish sample excludes energy products, which lowers the aggregate frequency.

(Table 3, Peter and Benjamin, 2010)

Tables 4(a) and (b) show the statistics of the product-specific and store-specific duration of price quotations in Hungary. Table 4(b) also shows the separate information of duration of price quotations in large department stores and small grocery stores, which reveals that large stores have a clear tendency with less frequent price adjustments. The reason why large department stores have lower tendency to change prices could be that their marginal revenue is more procyclical and steeper, leading to a greater real rigidity. Price cuts occur frequently, and the size of which is systematically smaller than price increases. 


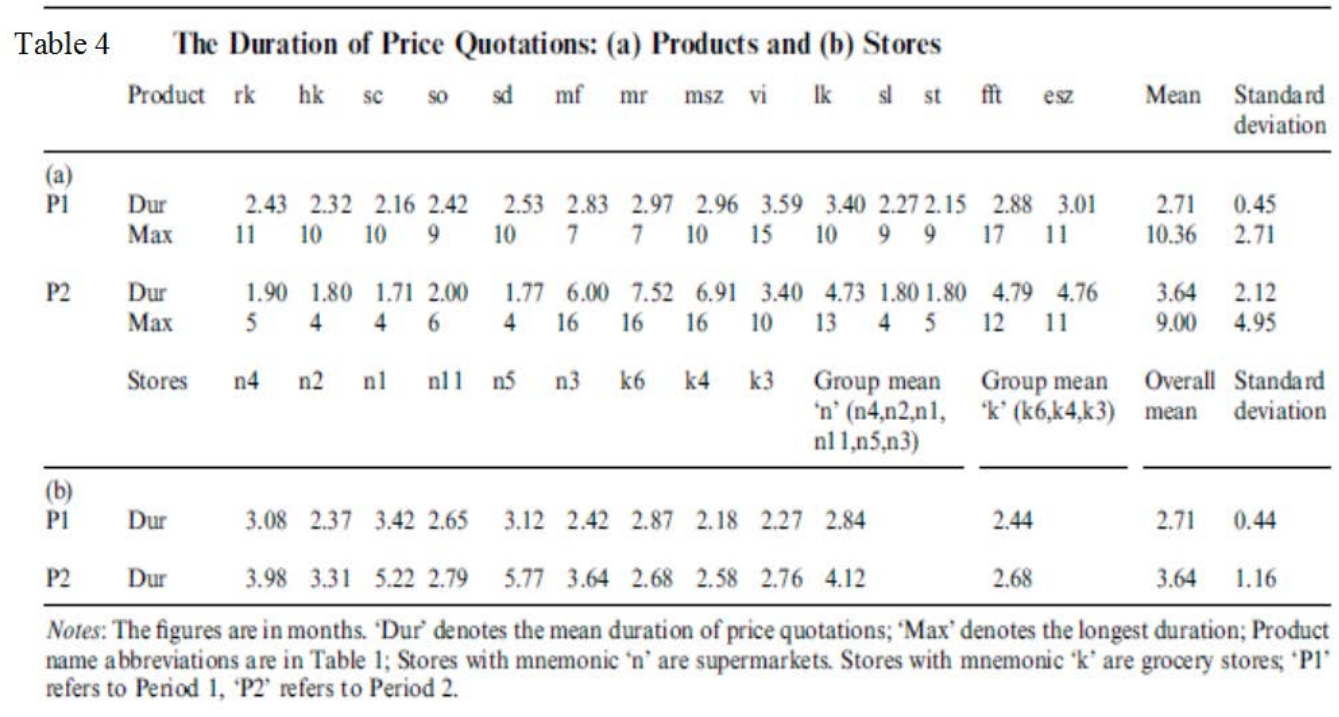

(Table 4, Attila, 2007)

To conclude, considering the fact that the prices are highly volatile or trending upwards, the results reveal that prices fluctuate less frequently and perform strong stickiness in developed countries, which supports the evidence for macroeconomic pricing models, with price adjustment exhibiting heterogeneity, state-dependence and lumpiness.

\section{Empirical Evidence for Developing Countries}

Some results about price stickiness have been obtained for developed countries. This section will answer the question ' Are prices also sticky in the developing countries?' by estimating the duration of price adjustment in four emerging Latin-American countries, namely, Chile, Brazil, Colombia, and Mexico. These four countries were chosen as a result of adopting similar monetary policy that is inflation targeting and experiencing a low and stable inflation rate.

The sample was collected from the construction of CPI in each of the four countries (Felipe and Mauricio, 2008). In each country, different groups of goods are classified relying on the type of individual products. In the Table 5, the term observation represents the price of individual product at a given time point, and the term price spell means the time interval between two price changes. According to this table, two general features about the duration can be obtained. Firstly, the table illustrates that the products that change price less frequently occupy more weights in the CPI basket for each of four economies, since the largest duration is found using the measure considering the CPI weights. Secondly, the duration distribution tends to be right-skewed due to the fact that the mean is always higher than the median. It indicates that products changing price more frequently account for greater weights in the numbers of observations. 


\begin{tabular}{|c|c|c|c|c|}
\hline Country & $\begin{array}{l}\text { Number of } \\
\text { Observations }\end{array}$ & Mean & Median & $\begin{array}{l}\text { Standard } \\
\text { Deviation }\end{array}$ \\
\hline \multicolumn{5}{|l|}{ Brazil (1999:8 - 2006:6) } \\
\hline All price spells & 27,390 & 1.51 & 1.00 & 1.36 \\
\hline Price spells averaged by individual trajectory(*) & 512 & 1.74 & 1.47 & 1.10 \\
\hline $\begin{array}{l}\text { Price spells averaged by individual trajectory( }(*) \\
\text { (Weighted) }\end{array}$ & 512 & 2.13 & 1.88 & 1.04 \\
\hline \multicolumn{5}{|l|}{ Colombia (1999:1 - 2006:10) } \\
\hline All price spells & 7,591 & 2.13 & 1.00 & 2.47 \\
\hline Price spells averaged by individual trajectory (*) & 176 & 2.68 & 2.24 & 1.49 \\
\hline $\begin{array}{l}\text { Price spells averaged by individual trajectory(*) } \\
\text { (Weighted) }\end{array}$ & 176 & 3.56 & 2.42 & 2.14 \\
\hline \multicolumn{5}{|l|}{ Chile (1998:12 - 2006:10) } \\
\hline All price spells & 21,422 & 2.09 & 1.00 & 2.94 \\
\hline Price spells averaged by individual trajectory (*) & 482 & 3.26 & 2.11 & 3.75 \\
\hline $\begin{array}{l}\text { Price spells averaged by individual trajectory(*) } \\
\text { (Weighted) }\end{array}$ & 482 & 3.42 & 2.12 & 4.09 \\
\hline \multicolumn{5}{|l|}{ Mexico $(1995: 1-2006: 10)$} \\
\hline All price spells & 23,747 & 1.60 & 1.00 & 2.09 \\
\hline Price spells averaged by individual trajectory (*) & 271 & 1.86 & 1.63 & 1.32 \\
\hline $\begin{array}{l}\text { Price spells averaged by individual trajectory(*) } \\
\text { (Weighted) }\end{array}$ & 271 & 2.06 & 1.77 & 1.45 \\
\hline
\end{tabular}

Additionally, it can be found that these emerging countries have a less degree of nominal rigidity with the duration of appropriately between two and three months, compared to the developed countries mentioned before. Finally, table 6 shows that the heterogeneity exists across the distinct product groups in terms of the average duration. For example, less-processed products such as food items tend to exhibit a less rigid price adjustment than others. 


\begin{tabular}{|c|c|c|c|c|c|c|}
\hline \multirow[b]{2}{*}{ Country/Group } & \multicolumn{3}{|c|}{ Unweighted } & \multicolumn{3}{|c|}{ Weighted } \\
\hline & Mean & Median & $\begin{array}{l}\text { Standard } \\
\text { Deviation }\end{array}$ & Mean & Median & $\begin{array}{l}\text { Standard } \\
\text { Deviation }\end{array}$ \\
\hline \multicolumn{7}{|l|}{ Brazil (1999:8 - 2006:6) } \\
\hline Food and Beverages & 1.33 & 1.27 & 0.26 & 1.57 & 1.47 & 0.37 \\
\hline Communication & 3.25 & 2.44 & 2.14 & 3.58 & 3.68 & 0.66 \\
\hline Education & 2.95 & 2.53 & 1.28 & 4.17 & 4.50 & 1.32 \\
\hline Household Articles & 1.55 & 1.53 & 0.20 & 1.64 & 1.65 & 0.19 \\
\hline Personal Expenses & 2.42 & 1.72 & 2.04 & 2.62 & 2.13 & 1.50 \\
\hline Medical Care & 2.41 & 2.13 & 1.01 & 2.35 & 2.25 & 1.05 \\
\hline Transportation & 3.04 & 2.14 & 2.54 & 2.09 & 1.88 & 0.90 \\
\hline Apparel & 1.59 & 1.53 & 0.27 & 1.63 & 1.62 & 0.25 \\
\hline Housing & 1.64 & 1.58 & 0.43 & 1.92 & 2.03 & 0.21 \\
\hline Total & 1.74 & 1.47 & 1.10 & 2.13 & 1.88 & 1.04 \\
\hline \multicolumn{7}{|l|}{ Colombia (1999:1 - 2006:10) } \\
\hline Food & 1.76 & 1.69 & 0.63 & 2.14 & 2.14 & 0.81 \\
\hline Culture, Entertainment and Recreation & 2.83 & 2.33 & 1.17 & 2.78 & 2.24 & 1.15 \\
\hline Education & 3.97 & 4.28 & 1.30 & 4.60 & 4.38 & 0.86 \\
\hline Other Expenses & 2.23 & 2.25 & 0.60 & 2.19 & 2.42 & 0.45 \\
\hline Medical Care & 2.27 & 2.30 & 0.65 & 1.95 & 2.24 & 0.63 \\
\hline Transportation and Communication & 2.75 & 2.19 & 1.28 & 2.57 & 2.00 & 1.35 \\
\hline Apparel & 4.70 & 4.38 & 2.03 & 5.12 & 4.84 & 1.76 \\
\hline Housing & 2.69 & 2.19 & 1.30 & 5.55 & 7.08 & 2.24 \\
\hline Total & 2.68 & 2.24 & 1.49 & 3.56 & 2.42 & 2.14 \\
\hline \multicolumn{7}{|l|}{ Chile (1998:12-2006:10) } \\
\hline Food & 1.65 & 1.43 & 0.71 & 2.01 & 1.48 & 0.97 \\
\hline Education and Entertainment & 6.34 & 3.21 & 8.51 & 8.51 & 7.15 & 9.12 \\
\hline Household Articles & 2.96 & 2.45 & 1.67 & 2.90 & 2.38 & 1.57 \\
\hline Other Expenses & 4.97 & 4.29 & 3.03 & 3.69 & 2.45 & 2.66 \\
\hline Medical Care & 3.07 & 2.25 & 1.80 & 3.84 & 2.74 & 2.37 \\
\hline Transportation & 3.15 & 2.38 & 2.43 & 2.36 & 1.50 & 2.14 \\
\hline Apparel & 4.76 & 4.43 & 3.51 & 4.35 & 1.94 & 3.78 \\
\hline Housing & 3.43 & 3.00 & 2.28 & 2.58 & 2.02 & 1.26 \\
\hline Total & 3.26 & 2.11 & 3.75 & 3.42 & 2.12 & 4.09 \\
\hline \multicolumn{7}{|l|}{ Mexico (1995:1 - 2006:10) } \\
\hline Food and Beverages & 1.48 & 1.48 & 0.37 & 1.71 & 1.65 & 0.49 \\
\hline Education and Entertainment & 2.71 & 1.97 & 1.82 & 2.30 & 1.87 & 1.20 \\
\hline Household Articles & 1.71 & 1.69 & 0.23 & 1.67 & 159 & 0.21 \\
\hline Other Services & 1.73 & 1.60 & 0.29 & 1.55 & 1.51 & 0.10 \\
\hline Medical Care & 1.53 & 1.47 & 0.21 & 1.61 & 1.59 & 0.21 \\
\hline Transportation & 2.72 & 2.06 & 2.04 & 2.60 & 2.64 & 1.09 \\
\hline Apparel & 1.79 & 1.75 & 0.24 & 1.81 & 1.79 & 0.21 \\
\hline Housing & 5.07 & 3.26 & 4.57 & 2.53 & 1.79 & 2.64 \\
\hline Total & 1.86 & 1.63 & 1.32 & 2.06 & 1.77 & 1.45 \\
\hline
\end{tabular}

(Table 6, Felipe and Mauricio, 2008)

Brazil can be taken as a more detailed example. Extensive data was collected from almost 500 products and services in 7 different sectors (Food, Housing, Apparel, Medical and Personal Care, Education and Recreation, Transportation and Other Goods and Services) from March 1996 to April 2006 (Gouvea, 2007). And about 9 million observations were involved in order to assess the price rigidity in Brazil. Table 7 shows how often does price change by CPI sector. It is clear that heterogeneity can be seen in price-setting behavior across different sectors. To be more precise, price adjustment in food sector is more frequent mainly due to seasonality. In addition, non-processed food, which is easier to be perishable, also results in high flexibility of price setting. Similarly, price in apparel sector is also affected by seasonality. However, high rigidity, represented by less flexibility and long duration, could be seen in those service sectors and possible reason should be the wage which is usually signed in contracts at the beginning of long-period employment. 
Frequency and Implied Duration of Price Changes by CPI Sector

\begin{tabular}{|c|c|c|c|c|}
\hline CPI Sector & Frequency & Mean Dur* & Mean Dur** & Median Dur \\
\hline Food & 0.42 & 2.41 & 1.86 & 1.67 \\
Other Goods and Services & 0.19 & 5.29 & 4.78 & 3.67 \\
Education and Recreation & 0.15 & 6.68 & 6.17 & 4.63 \\
Housing & 0.43 & 2.3 & 1.75 & 1.59 \\
Medical and Personal Care & 0.25 & 3.93 & 3.41 & 2.73 \\
Transportation & 0.35 & 2.82 & 2.29 & 1.95 \\
Apparel & 0.58 & 1.71 & 1.14 & 1.19 \\
\hline Overall CPI & 0.37 & 2.68 & 2.14 & 1.86 \\
\hline
\end{tabular}

Note: *Assuming whenever prices are changed it occurs once within a given month interval, ${ }^{* *}$ Assuming price can change at any point in time.

(Table 7, Gouvea, 2007)

In conclusion, prices in Brazil are more flexible which represents less rigidity. In addition, evident heterogeneity could be seen on the price adjustment behavior across different sectors.

\section{Special Cases}

Apart from the regularities found among different kinds of countries, some special elements, concerning the seasonality and holidays price changes, also exist. According to the investigation by Aucremanne and Dhyne (2004), there is some evidence of seasonal pattern representing the price changes frequency. Their empirical evidence in Belgium are shown in figure 2 below in detail.

Fic $\quad$ onal pattern of the frequency of price changes ${ }^{1}$

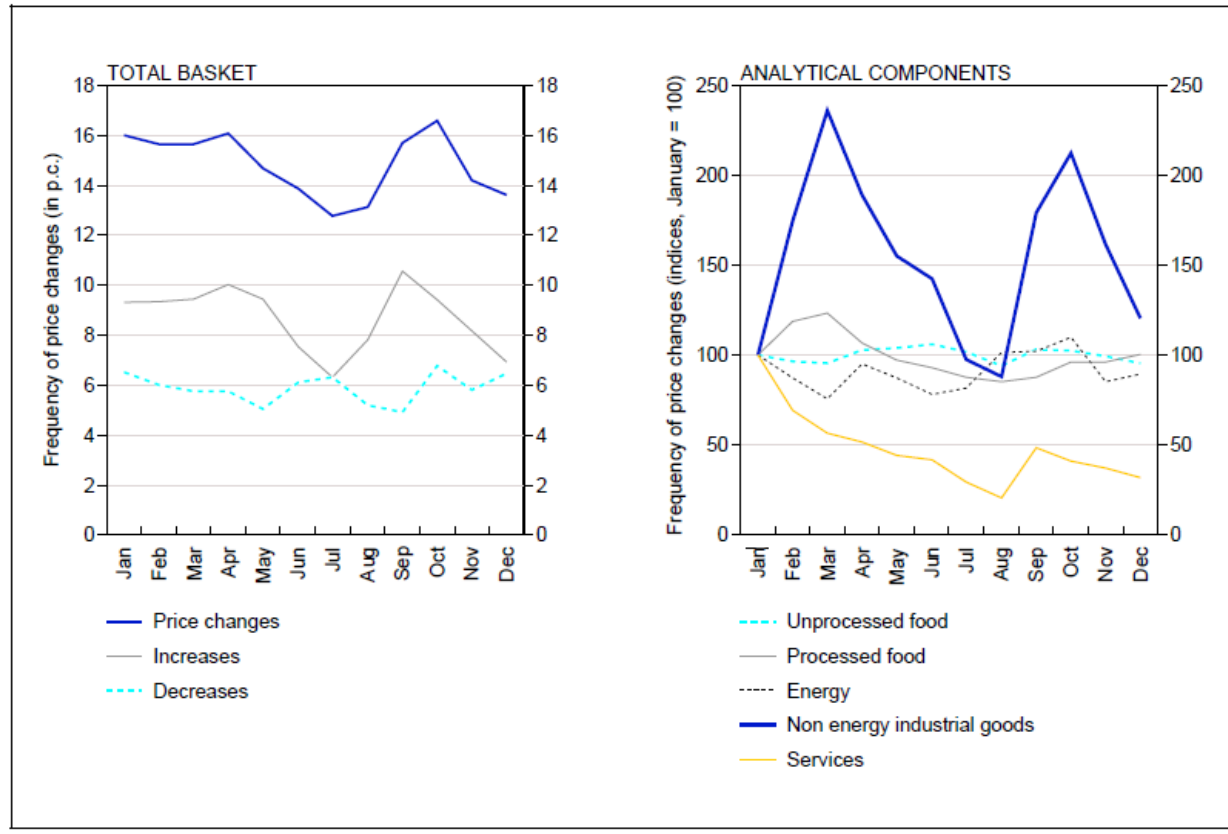

\footnotetext{
Sources: FPS, NBB.

The seasonal patterns are computed as simple averages, excluding the months affected by VAT rate changes (April 1992, January 1994 and January 1996).
}

(Figure 2, Aucremanne and Dhyne, 2004)

After excluding the value added tax, Figure 2 demonstrates that the quantity of price changes peaks at almost 16 times per month for the total basket from January to April and from September to October. In terms of the classification of price increases and decreases, the former is more obviously affected by seasonal trend than the latter, because the summer and winter sales are excluded in order to capture the pure seasonality feature. Besides, among various commodities, the impacts on non energy industrial goods and services are more evident, which reveals relatively high seasonal price flexibilities. 
In the aspect of holidays, Levy et al. (2010) state that the price changes of the Thanksgiving-Christmas period in the U.S. is less frequent. This statement can be shown in table 8 below. It demonstrates that for most categories, the average quantity of retail price changes is lower in holidays. The explanations mainly focus on the menu costs. First of all, shops or supermarkets become more popular during holidays and the opportunity cost faced by retailers of changing prices peaks at that time. Secondly, the labor cost of extra hiring hour also induces a less price change frequency.

\begin{tabular}{|c|c|c|c|c|}
\hline Product category & Non-holiday & Holiday & $\%$ difference & $t$-statistic \\
\hline Analgesics & 12.38 & 10.47 & -15 & $-1.59^{\mathrm{c}}$ \\
\hline Bottled juices & 26.21 & 22.10 & -16 & $-1.72^{\mathrm{c}}$ \\
\hline Cereals & 21.41 & 14.07 & -34 & $-2.79^{\mathrm{a}}$ \\
\hline Cheeses & 45.72 & 43.05 & -6 & -0.75 \\
\hline Crackers & 14.51 & 12.46 & -14 & -1.01 \\
\hline Canned soups & 27.45 & 27.89 & 2 & 0.18 \\
\hline Dish detergents & 11.05 & 10.52 & -5 & -0.47 \\
\hline Frozen entrees & 53.60 & 34.18 & -36 & $-5.98^{\mathrm{a}}$ \\
\hline Frozen juices & 16.98 & 15.60 & -8 & -0.86 \\
\hline Fabric softeners & 10.36 & 8.01 & -23 & $-2.16^{\mathrm{a}}$ \\
\hline Laundry detergents & 17.26 & 13.99 & -19 & $-2.23^{\mathrm{a}}$ \\
\hline Paper towels & 7.15 & 5.49 & -23 & $-2.12^{b}$ \\
\hline Refrigerated juices & 18.40 & 16.42 & -11 & $-1.61^{\mathrm{c}}$ \\
\hline Soft drinks & 117.83 & 109.84 & -7 & $-1.53^{c}$ \\
\hline Snack crackers & 24.07 & 31.07 & 29 & $2.21^{\mathrm{a}}$ \\
\hline Canned fish & 13.32 & 11.05 & -17 & $-15.1^{\mathrm{a}}$ \\
\hline Toothpastes & 18.8 & 15.5 & -18 & $-1.33^{c}$ \\
\hline Toilet tissues & 8.75 & 6.74 & -23 & $-2.25^{\mathrm{a}}$ \\
\hline Total & 465.25 & 408.45 & -12 & $-4.72^{\mathrm{a}}$ \\
\hline
\end{tabular}

Retail prices are the actual transaction prices, as recorded by the store scanners. The prices are changed at the weekly frequency, which is standard retail food industry practice. As the holiday period in each year, we define the week before Thanksgiving through the week of Christmas, a total six-week period. The remaining weeks are defined as non-holiday periods. Superscripts $a, b$ and $c$ indicate statistical significance at 1,5 and $10 \%$, respectively.

(Table 8, Levy et al., 2010)

\section{Conclusion}

After examining through the evidence on price behaviors in both developed and developing countries, there is no explicit conclusion. To roughly conclude, the developed countries possess more rigid price behavior in respond to economic shocks. On the contrary, the price in developing countries would behave more flexible to the economic shocks. It is worth noting that there exist predominant pronouncing inflation within the developing countries in our developing evidence. These could possibly be the reasons explaining the disparity among the two groups.

\section{References}

[1] Aucremanne, L. \& Dhyne, E. (2004), How frequently do prices change? Evidence based on the micro data underlying the Belgian CPI.

[2] Bergen, M., Dutta, S. \& Levy, D. (2002), Heterogeneity in price rigidity: evidence from a case study using microlevel data. Journal of Money and Credit Banking 34: 197 - 220

[3] Caplin, A.S., Leahy, J. (1991), State-dependent pricing and the dynamics of money and output. Quarterly Journal of Economics 106: 683 - 708

[4] Carl, E. Walsh (2010), Monetary Theory and Policy, Third Edition, The MIT Press.

[5] Emmanuel, D. (2006), Journal of Economic Perspectives, Volume 20, Number 2-Spring 2006 -Pages 171 - 192. 
[6] Felipe, M. and Mauricio, T. (2008), Price Stickiness in Emerging Economies: Empirical Evidence for Four Latin-American Countries, University of Chile.

[7] Gouvea, S. (2007), Price Rigidity in Brazil: Evidence from CPI Micro Data, Central Bank of Brazil Working Paper 143.

[8] Levy, D., Chen, H. A. \& Müller, G., Dutta, S., \& Bergen, M. (2010), Holiday price rigidity and cost of price adjustment. Economica, 77(305), 172-198.

[9] Romer, D. (2012), Advanced Macroeconomics, 4th ed., McGraw-Hill. 